\title{
ANALISIS FAKTOR-FAKTOR YANG MEMPENGARUHI PENERAPAN TRANSFER PRICING PADA PERUSAHAAN MANUFAKTUR YANG TERDAFTAR DI BURSA EFEK INDONESIA TAHUN 2016-2019
}

\author{
Nia Tresnawaty, SE, M.Ak., \\ niatresna@yahoo.com
}

Fakultas Ekonomi - Program Studi Akuntansi Universitas Satya Negara Indonesia

\begin{abstract}
ABSTRAK
Tujuan penelitian ini adalah untuk mengetahui faktor-faktor yang mempengaruhi penerapan transfer pricing. Populasi dalam penelitian ini adalah perusahaan Manufaktur yang terdaftar di Bursa Efek Indonesia pada tahun 2016-2019.

Penelitian ini menggunakan data sekunder yang berasal dari laporan keungan Bursa Efek Indonesia dan Website Perusahaan. Perusahaan Sampel ditentukan dengan metode purposive sampling sehingga diperoleh 260 data yang dijadikan sampel. Analisis data menggunakan metode analisis regressi logistik dengan bantuan sistem SPSS versi 23.

Hasil penelitian menunjukan secara parsial, beban pajak dan tunneling incentive berpengaruh terhadap penerapan transfer pricing sedangkan mekanisme bonus tidak berpengaruh. Dan Secara simultan beban pajak, tunneling incentive dan mekanisme bonus berpengaruh terhadap penerapan transfer pricing.

Kata Kunci : Beban Pajak, Tunneling Incentive, Mekanisme Bonus dan Transfer Pricing
\end{abstract}

\section{PENDAHULUAN}

\section{Latar Belakang}

Menghadapi era globalisasi yang saat ini semakin modern, menyebabkan perekonomian berkembang tanpa batas membuat batas-batas negara menjadi hampir tidak ada, bahkan negara sudah bukan menjadi batasan. Masalah-masalah baru bermunculan. Salah satunya yakni pada perusahaan multinasional yang akan menghadapi masalah perbedaan pajak yang berlaku di setiap negara.

Perbedaan tarif pajak ini membuat perusahaan multinasional mengambil keputusan untuk melakukan transfer pricing. Dengan penerapan transfer pricing ini menimbulkan permasalahan yang sampai saat ini sering terjadi, diantaranya masalah pajak, ketentuan anti-dumping, bea cukai, persaingan usaha yang tidak sehat, dan masalah internal manajemen, serta masih banyak masalah lain yang berhubungan dengan adanya transfer pricing. Di Indonesia transfer pricing diatur dalam Pasal 18 Undang- Undang Nomor 36 Tahun 2008 tentang pajak penghasilan. Peraturan tersebut memuat beberapa hal, yaitu pengertian hubungan istimewa, wewenang menentukan perbandingan utang dan modal, dan wewenang untuk melakukan koreksi dalam transaksi yang tidak wajar. Adanya hubungan 
istimewa dapat mengakibatkan ketidakwajaran harga, biaya, atau imbalan lain yang direalisasikan dalam suatu transaksi usaha.

Tujuan awal transfer pricing yaitu sebagai penilaian kinerja antar anggota serta divisi perusahaan. Namun, perkembangan zaman telah mampu mengubah fungsi awal transfer pricing tersebut. Praktik transfer pricing juga sering digunakan untuk melakukan menajemen pajak yaitu sebuah usaha dimana perusahaan meminimalkan jumlah pajak yang harus dibayar. karena pajak mempunyai sifat memaksa dan memang merupakan salah satu hal yang perlu diminimalisir hingga dihindari oleh banyak perusahaan (Mangoting, 2004). Beberapa peneliti telah mencoba meneliti tentang hubungan pajak pada transfer pricing, diantaranya oleh Yuniasih dkk. (2012), Hartati dkk. (2015), dan Noviastika dkk. (2016) yang menemukan bahwa pajak berpengaruh terhadap keputusan transfer pricing. Namun hasil penelitian dari Marfuah (2014) menunjukkan hal yang berbeda, yaitu tidak adanya pengaruh antara pajak terhadap keputusan perusahaan dalam melakukan transfer pricing.

Keputusan Transfer pricing juga dipengaruhi oleh tunneling. Gilson dan Gordon (2003) menyatakan ada beberapa langkah yang bisa ditempuh majority shareholder untuk memperoleh keuntungan pribadi melalui kontrol kebijakan operasi perusahaan seperti deviden, bonus, gaji, dan tunjangan dan langkah untuk mendapat keuntungan pribadi melalui kebijakan kontraktual antara lain dengan tunneling. Bisa dikatakan bahwa perusahaan akan melakukan hal yang membuat biaya pajak kecil. Tunneling adalah tindakan majority shareholder yang mengalihkan aset dan profit perusahaan untuk memperoleh manfaat privat, namun bebannya juga ikut ditanggung oleh minority shareholder. Kegiatan tunneling berhubungan erat dengan kepemilikan saham pada perusahan tersebut (Mutamimah, 2009). Penelitian tentang tunneling incentive telah dilakukan oleh Yuniasih, Rasmini dan Wirakusuma (2012), yang menemukan tunneling incentive berpengaruh positif pada keputusan perusahaan manufaktur dalam melakukan transfer pricing. Namun penelitian yang dilakukan oleh Melani (2016) memperoleh hasil bahwa Tunneling Incentive tidak berpengaruh terhadap keputusan melakukan transfer pricing.

Selain pajak dan tunneling incentive ada juga mekanisme bonus, berdasarkan penelitian Refgia (2017) mengemukakan bahwa mekanisme bonus adalah kompensasi tambahan atau penghargaan yang diberikan kepada pegawai atas keberhasilan pencapaian tujuan-tujuan yang di targetkan oleh perusahaan. Mekanisme bonus berdasarkan besarnya laba akan membuat direksi berupaya untuk melakukan manipulasi laba bahkan juga dilakukan manipulasi laba bersih dengan tujuan mampu memaksimalkan bonus diterimanya. Penelitian mengenai pengaruh mekanisme bonus terhadap transfer pricing telah dilakukan oleh Hartati (2015) dan menghasilkan hasil penelitian bahwa mekanisme bonus berpengaruh secara signifikan terhadap transfer pricing. Berbeda dengan penelitian yang telah dilakukan oleh Mispiyanti (2015) yang mendapatkan kesimpulan bahwa mekanisme bonus tidak berpengaruh terhadap keputusan perusahaan melakukan transfer pricing

Jurnal Ilmiah Akuntansi dan Ekonomi Volume. 5 Nomor. 2, Agustus 2020 Hal. 19 
Berdasarkan uraian yang berhubungan dengan transfer pricing, pajak, tunneling incentive, serta mekanisme bonus tersebut, maka peneliti akan menguji kembali perusahaan-perusahaan Manufaktur yang terdaftar di Bursa Efek Indonesia periode tahun 2016-2019. Berdasarkan hal tersebut, maka peneliti melakukan penelitian yang berjudul "Analisis Faktor-Faktor Yang Mempengaruhi Penerapan Transfer Pricing Pada Perusahaan Manufaktur Yang Terdaftar Di Bursa Efek Indonesia Tahun 2016-2019".

\section{Perumusan Masalah}

Adapun rumusan masalah yang akan menjadi kajian dalam penelitian ini adalah untuk mengetahui:

1. Apakah pajak berpengaruh terhadap penerapan transfer pricing?

2. Apakah tunneling incentive berpengaruh terhadap penerapan transfer pricing?

3. Apakah mekanisme bonus berpengaruh terhadap penerapan transfer pricing?

\section{Tujuan penelitian}

Tujuan penelitian ini adalah sebagai berikut :

1. Untuk mengetahui apakah pajak berpengaruh terhadap penerapan penerapan transfer pricing.

2. Untuk mengetahui apakah tunneling incentive berpengaruh terhadap penerapan transfer pricing.

3. Untuk mendapatkan bukti empiris mengenai pengaruh mekanisme bonus terhadap penerapan transfer pricing.

\section{LANDASAN TEORI}

\section{Teori Agensi (Agenchy Theory)}

Menurut Scott (2015:358), teori keagenan merupakan cabang dari game theory yang mempelajari skema dari kontrak untuk memotivasi agen yang rasional untuk bertindak sesuai keinginan dari principal. Hubungan agensi ada ketika salah satu pihak (principal) menyewa pihak lain (agen) untuk melaksanakan jasa dan dalam hal tersebut, principal mendelegasikan wewenang kepada agen untuk membuat keputusan.

Namun, dalam praktiknya kadang kala terjadi konflik yang disebabkan karena masing-masing pihak memiliki kepentingan yang berbeda. Agen sering kali bertindak hanya untuk kepentingannya sendiri dan mengesampingkan kepentingan principal. Hal inilah yang menyebabkan terjadinya konflik, konflik ini disebut dengan konflik keagenan.

Munculnya konflik disebabkan karena adanya asimetri informasi atau adanya kesenjangan informasi antara agen selaku pihak yang menyediakan informasi dengan principal dan stakeholders sebagai pengguna informasi. Informasi lebih banyak dimiliki oleh manajer dapat memicu tindakan oportunistik sesuai dengan kepentingan untuk memaksimalkan utilitasnya. Sedangkan bagi principal sulit mengontrol secara efektif tindakan yang dilakukan oleh manajemen karena hanya memilki sedikit informasi dari seluruh informasi yang ada. 


\section{Teori Akuntansi Positif}

Positive accounting theory dikembangkan oleh Watts \& Zimmerman (1986) dimana memaparkan faktor-faktor ekonomi tertentu yang bisa dikaitkan dengan perilaku manajer atau para pembuat laporan keuangan. Sehingga, teori ini diharapkan dapat membantu untuk menjelaskan dan memprediksi praktik akuntansi. Adanya perkembangan dari suatu teori akuntansi positif akan dapat menjelaskan dari why accounting is what it is, why accountants do what they do, dan apa pengaruh dari fenomena ini terhadap manusia dan penggunaan sumber daya (Jensen $\&$ Meckling, 1976 dalam Setijaningsih, 2012).

Dengan teori akuntansi positif ini akan membuat manajer bersikap lebih berhati-hati (konservatisme) dalam melakukan penghindaran pajak. Menjelaskan (to explain) dan memprediksi (to predict) dalam teori akuntansi positif terhadap praktik transfer pricing untuk menekan beban pajak perusahaan.

Dimana Menjelaskan (to explain), memberikan alasan-alasan terhadap praktik transfer pricing dengan motivasi mengurangi beban pajak sehingga laba perusahaan meningkat yang dilakukan manajer dan memprediksi (to predict), kondisi kapan manajer akan melakukan praktik transfer pricing dengan motivasi mengurangi beban pajak sehingga laba perusahaan meningkat dengan memanfaatkan celah-celah yang ada.

\section{Transfer Pricing}

Transfer pricing adalah harga yang terkandung pada setiap produk atau jasa dari satu divisi yang di transfer ke divisi yang lain dalam perusahaan yang sama atau antar perusahaan yang mempunyai hubungan istimewa. Transaksi transfer pricing dapat terjadi pada divisi-divisi dalam satu perusahaan, antar perusahaan lokal, atau perusahaan lokal dengan perusahaan yang ada di luar negeri (Hartati, 2014).

Namun menurut Rahayu (2010) dalam konteks perpajakan transfer pricing dapat digunakan untuk merekayasa pembebanan harga suatu transaksi antara perusahaan-perusahaan yang mempunyai hubungan istimewa atau disebut dengan related parties dalam rangka meminimalkan beban pajak yang terutang secara keseluruhan atas grup perusahaan. Sehingga, untuk mencegah penghindaran pajak karena penentuan harga tidak wajar (non arm's length price), muncul Peraturan Dirjen Pajak No.PER-43/PJ/2010. Aturan ini membahas penerapan prinsip kewajaran dan kelaziman usaha (arm's length principles) terkait transaksi antara wajib pajak dengan pihak yang memiliki hubungan istimewa. Aturan ini mengharuskan wajib pajak untuk menggunakan nilai pasar wajar dalam bertransaksi dengan pihak istimewa (Suryana, 2012).

Menurut Pernyataan Standar Akuntansi Keuangan (PSAK) No. 7 Tahun 2010, pihak-pihak yang mempunyai hubungan istimewa adalah bila satu pihak mempunyai kemampuan untuk mengendalikan pihak lain, atau mempunyai pengaruh signifikan atas pihak lain dalam mengambil keputusan. Transaksi antara pihak-pihak yang mempunyai hubungan istimewa adalah suatu pengalihan sumber daya, atau kewajiban antara pihak-pihak yang mempunyai hubungan istimewa, tanpa menghiraukan apakah suatu harga diperhitungkan.

Jurnal Ilmiah Akuntansi dan Ekonomi Volume. 5 Nomor. 2, Agustus 2020 Hal. 21 


\section{Beban Pajak}

Menurut Pohan (2016) pajak adalah salah satu sumber pendapatan negara yang sangat penting bagi pelaksanaan dan peningkatan pembangunan nasional yang bertujuan untuk meningkatkan kemakmuran dan kesejahteraan masyarakat.

Menurut Waluyo (2016) pajak adalah iuran kepada negara (yang dapat dipaksakan) yang terutang oleh yang wajib membayarnya menurut peraturan peraturan, dengan tidak mendapat prestasi kembali, yang langsung dapat ditunjuk, dan yang gunanya adalah untuk membayar pengeluaran - pengeluaran umum berhubung dengan tugas negara yang menyelenggarakan pemerintahan.

Menurut Undang-Undang Nomor 28 Tahun 2007, pajak adalah kontribusi wajib kepada negara yang terutang oleh orang pribadi atau badan yang bersifat memaksa berdasarkan undang-undang, dengan tidak mendapatkan imbalan secara langsung dan digunakan untuk keperluan negara bagi sebesar-besarnya kemakmuran rakyat. Pungutan wajib yang dibayar rakyat untuk negara dan akan digunakan untuk kepentingan pemerintah dan masyarakat umum. Rakyat yang membayar pajak tidak akan merasakan manfaat dari pajak secara langsung, karena pajak digunakan untuk kepentingan umum bukan untuk kepentingan pribadi.

Berdasarkan PSAK 46 (2014) tentang beban pajak (penghasilan pajak) adalah jumlah gabungan pajak kini dan pajak tangguhan yang diperhitungkan dalam menentukan laba-rugi pada suatu periode kemudian dipadankan dengan dengan laba akuntansi. Beban pajak (penghasilan pajak) terdiri dari beban pajak kini (penghasilan pajak kini) dan beban pajak tangguhan (penghasilan pajak tangguhan).

\section{Tunneling Incentive}

Menurut Johnson (2000) dalam Wafiroh dan Hapsari (2016) kegiatan ekspansi besar-besaram yang dilakukan oleh perusahaan-perusahaan unutk mempercepet pertumbuhannya telah banyak menimbulkan konglomerasi. Konglomerasi memberikan kontribusi besar dalam krisis ekonomi nasional yang sekaligus mendominasi perekonomian nasional, hal ini sering terjadi terutama di Indonesia. Pemegang saham minoritas dan pihak ekternal lainnya sering dirugikan oleh pemegang saham kendali karena berpengaruh kuat yang menyebabkan timbulnya resiko ekploitasi seperti karakteristik kelompok bisnis konglomerat. Kemampuan mengendalikan kegiatan bisnis pada satu pihak muncul akibat kepemilikan saham yang terkonsentrasi pada salah satu pihak pengendali yang akan menimbulkan kegiatan tunneling. Tunneling merupakan aktivitas pengalihan aset dalam keuntungan keluar perusahaan untuk kepententingan pemegang saham pengendali perusahaan tersebut.

Menurut Mispiyanti (2015) Tunneling incentive memiliki indikator dengan $20 \%$ atau lebih persentase kepemilikan saham yang dimiliki oleh pemegang saham yang berapa di negara lain dengan ketentuan memiliki tarif pajak lebih rendah dari Indonesia. Selain itu, sesuai dengan PSAK Nomor 15 pengaruh signifikan diperoleh dari presentase $20 \%$ atau lebih kepemilikan saham. 


\section{Mekanisme Bonus}

Menurut Hartati (2014), mekanisme bonus direksi dapat diartikan sebagai pemberian imbalan diluar gaji kepada direksi perusahaan atas hasil kerja yang dilakukan dengan melihat prestasi kerja direki itu sendiri. Prestasi kerja yang dilakukan dapat dinilai dan diukur berdasarkan suatu penilaian yang telah ditentukan perusahaan secara objektif.

Selain itu menurut Refgia (2017) mekanisme bonus adalah kompensasi tambahan atau penghargaan yang diberikan kepada pegawai atas keberhasilan pencapaian tujuan-tujuan yang ditargetkan oleh perusahaan. Mekanisme bonus berdasarkan laba merupakan cara yang paling sering digunakan perusahaan dalam memberikan penghargaan kepada direksi atau manajer. Maka, karena berdasarkan tingkat laba direksi atau manajer dapat memanipulasi laba tersebut untuk memaksimalkan penerimaan bonus.

Mengingat bahwa mekanisme bonus berdasarkan pada besarnya laba, yang merupakan cara paling populer dalam memberikan penghargaan kepada direksi/manajer, maka adalah logis bila direksi yang remunerasinya didasarkan pada tingkat laba akan memanipulasi laba tersebut untuk memaksimalkan peneriman bonus dan remunerasinya.

Jadi, dapat disimpulkan bahwa mekanisme bonus merupakan salah satu strategi atau motif perhitungan dalam akuntansi yang tujuannya adalah untuk memberikan penghargaan kepada direksi atau manajemen dengan melihat laba perusahaan secara keseluruhan. Karena sebagai akibat dari adanya praktik transfer pricing maka tidak menutup kemungkinan akan terjaadi kerugian pada salah satu divisi atau subunit.

\section{METODE PENELITIAN}

\section{Jenis Data, Sumber Data dan Objek Penelitian}

Penelitian menggunakan data sekunder. Data yang digunakan yakni diambil dari laporan keuangan dan annual report di Bursa Efek Indonesia (BEI) periode 2016 2019 yang diakses melalui website http://www.idx.co.id. Adapun Objek dalam penelitian ini adalah perusahaan manufaktur yang terdaftar di Bursa Efek Indonesia. Teknik pengumpulan data yang digunakan dalam penelitian ini adalah studi kepustakaan, observasi dan riset internet.

\section{Kerangka Pemikiran}

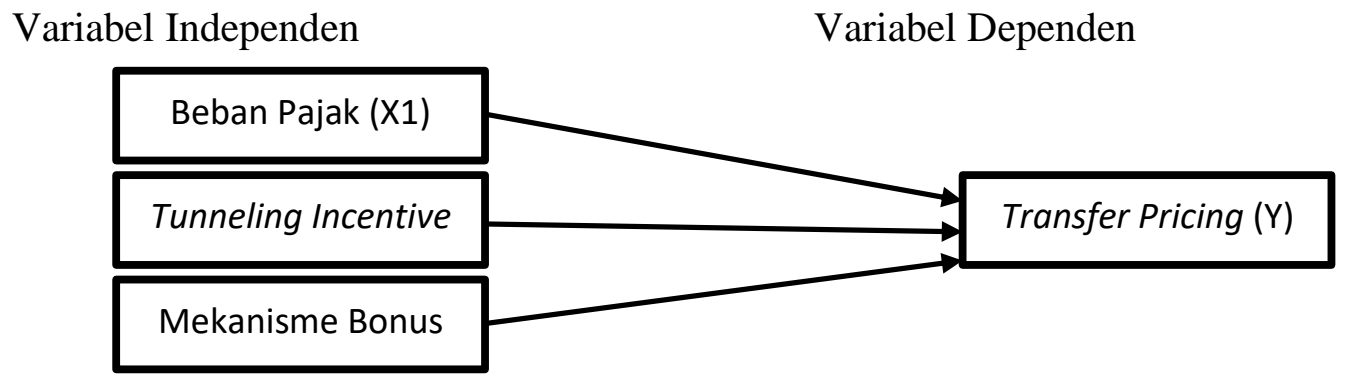

\section{Gambar 1.}

\section{Kerangka Pemikiran}




\section{Metode Analisis}

Metode analisis data dalam penelitian ini adalah dengan menggunakan teknik analisis kuantitatif. Menggunakan model regresi logistik (logistic regression) dengan bantuan SPSS. Variabel independen non metrik dalam penelitian ini adalah Transfer Pricing yang dinyatakan dengan variabel dummy. Dimana perusahaan yang melakukan transfer pricing diberi kode 1 dan untuk perusahaan yang tidak melakukan transfer pricing diberi nilai 0 .

Dalam penelitian ini digunakan analisis regresi logistik. Analisis dilakukan dengan melihat pengaruh masing-masing variabel independen terhadap variabel dependen. Adapun model regresi logistik yang terbentuk adalah:

$$
\begin{array}{lll}
\text { Ln }(\mathbf{Y} / \mathbf{1}-\mathbf{Y})= & \boldsymbol{\beta} \mathbf{0}+\boldsymbol{\beta 1 X} \mathbf{X}+\boldsymbol{\beta 2 X} \mathbf{2}+\boldsymbol{\beta 3 X 3}+\boldsymbol{\varepsilon} \\
\begin{array}{l}
\text { Keterangan: } \\
\text { Ln }(\mathrm{Y} / 1-\mathrm{Y})
\end{array} & =\text { Logaritma probabilitas perusahaan melakukan } \\
& \text { transfer pricing } \\
\beta 0 & =\text { Konstanta } \\
\mathrm{X} 1 & =\text { Beban Pajak } \\
\mathrm{X} 2 & =\text { Tunneling Incentive } \\
\mathrm{X} 3 & =\text { Mekanisme Bonus } \\
\beta 1-\beta 2-\beta 3 & =\text { Koefisien regresi variabel Independen } \\
\varepsilon & =\text { Error term }
\end{array}
$$

\section{Teknik Analisis Data}

Langkah - langkah analisis dalam uji regression logistic adalah sebagai berikut:

1. Menilai Keseluruhan Model

Uji ini digunakan untuk menilai model yang telah dihipotesiskan telah fit atau tidak dengan data. Hipotesis untuk menilai model fit adalah:

$\mathrm{H}_{0}$ : Model yang dihipotesiskan fit dengan data

$\mathrm{H}_{\mathrm{a}}$ : Model yang dihipotesiskan tidak fit dengan data

Dari hipotesis ini, agar model fit dengan data maka $\mathrm{H} 0$ harus diterima. Statistik yang digunakan berdasarkan Likelihood. Likelihood L dari model adalah probabilitas bahwa model yang dihipotesiskan menggambarkan data input. Adanya pengurangan nilai antara $-2 \log \mathrm{L}$, awal (initial - $2 \log \mathrm{L}$, function) dengan nilai -2LogL pada langkah berikutnya menunjukkan bahwa model yang dihipotesiskan Fit dengan data (Ghozali, 2016).

2. Menilai Kelayakan Model Regresi

Kelayakan model regresi dinilai dengan menggunakan Hosmer and Lemeshow Goodness of Fit Test. Hipotesis untuk menilai kelayakan model regresi adalah:

$\mathrm{H}_{0}$ : Tidak ada perbedaan antara model dengan data

$\mathrm{H}_{1}$ : Ada perbedaan antara model dengan data

Jika nilai statistik Hosmer and Lemeshow Goodness of Fit kurang dari 0,05, maka hipotesis nol ditolak yang berarti ada perbedaan signifikansi antara model dengan nilai observasinya sehingga Goodness of Fit model tidak baik karena model tidak dapat memprediksi nilai observasinya. Jika nilai Hosmer and 
Lemeshow Goodness of Fit lebih besar daripada 0,05 maka hipotesis nol tidak dapat ditolak dan berarti model mampu memprediksi nilai observasinya atau dapat dikatakan model dapat diterima karena sesuai dengan data observasinya (Ghozali, 2016:329).

\section{Hipotesis Penelitian}

Adapun hipotesis yang akan diuji adalah sebagai berikut:

$\mathrm{H}_{01}$ : Pajak tidak berpengaruh terhadap keputusan perusahaan melakukan Transfer Pricing

$\mathrm{H}_{\mathrm{a} 1}$ : Pajak berpengaruh terhadap keputusan perusahaan melakukan Transfer Pricing

$\mathrm{H}_{02}$ : Tunneling Incentive tidak berpengaruh terhadap keputusan perusahaan melakukan Transfer Pricing

$\mathrm{H}_{\mathrm{a} 2}$ : Tunneling Incentive berpengaruh terhadap keputusan perusahaan melakukan Transfer Pricing

$\mathrm{H}_{03}$ : Mekanisme Bonus tidak berpengaruh terhadap keputusan perusahaan melakukan Transfer Pricing

$\mathrm{H}_{\mathrm{a} 3}$ : Mekanisme Bonus berpengaruh terhadap keputusan perusahaan melakukan Transfer Pricing

\section{Variabel dan Skala Penelitian}

\section{Variable Independen}

Variabel independen dalam penelitian ini ada tiga yaitu Beban Pajak, Tunneling Incentive, dan Mekanisme Bonus.

\section{a. Beban Pajak (X1)}

Pajak penghasilan yang dihitung berbasis pada penghasilan kena pajak yang sesungguhnya dibayar kepada pemerimtah, disebut sebagai sebagai $\mathrm{PPh}$ terutang sedangkan pajak penghasilan yang dihitung berbasis penghasilan sebelum pajak disebut sebagai beban pajak penghasilan (Zain, 2008).

Salah satu cara mengukur seberapa baik sebuah perusahaan mengelola pajaknya adalah dengan melihat tarif pajak efektifnya. Pajak dalam penelitian ini diproksikan dengan effective tax rate yang merupakan perbandingan tax expense dikurangi deferred tax expense dibagi dengan laba sebelum pajak (Yuniasih et al., 2012).

\section{b. Tunneling Incentive (X2)}

$$
\mathrm{ETR}=\frac{\text { Tax Expense }- \text { Differed Tax Expense }}{\text { Earning Before Tax }} \times 100 \%
$$

Pada penelitian ini didasarkan pada besarnya kepemilikan saham yang melebihi 20\% (dua puluh persen). Entitas dianggap berpengaruh signifikan baik secara langsung ataupun tak langsung terhadap entitas lainnya apabila menyertakan modal $20 \%$ atau lebih berdasarkan Pernyataan Standar Akuntansi Keuangan (PSAK) No. 15.

Tunneling incentive adalah suatu perilaku dari pemegang saham mayoritas yang mentransfer aset dan laba ke perusahaan untuk kepentingan mereka sendiri, namun pemegang saham minoritas ikut menanggung biaya yang mereka bebankan (hartati et al., 2015). 
Pemindahan aset dan laba dapat dilakukan dengan berbagai cara, salah satunya adalah dengan melalui transfer pricing (Noviastika et al., 2016) Transaksi ini digunakan untuk tujuan demi meningkatkan keuntungan laba pemegang saham mayoritas Menurut Wafiroh dan Hapsari (2015). Menurut Andraeni (2017) Variabel Tunneling incentive diproksikan dengan perhitungan:

$$
\text { TNC }=\frac{\text { Kepemilikan Saham Terbanyak }}{\text { Jumlah Saham Yang Beredar }} \times 100 \%
$$

\section{c. Mekanisme Bonus (X3)}

Agar manajer termotivasi mau bekerja lebih baik dan keras maka pemilik menjanjikan sejumlah bonus yang akan diberikan apabila kinerja yang dicapainya di atas rata-rata periode sebelumnya (Sulistyanto, 2008). Mekanisme bonus adalah salah satu kebijakan dalam akuntansi yang populer untuk meningkatkan kinerja direksi dalam meningkatkan laba perusahaan dan ini dapat memaksimalkan penerimanaan kompensasi bonus kepada direksi atas hasil kinerja yang baik terhadap perusahaan, karena menyangkut kesejahteraan para eksekutif di internal perusahaan (Gayatrie 2014). Sehingga untuk variabel ini akan diukur dengan rumus ITRENDLB yaitu berdasarkan prosentase pencapaian laba bersih pada tahun t terhadap laba bersih pada tahun t-1 (Suryatiningsih 2009) dan (Irpan 2010).

$$
\text { ITTRENDLB }=\frac{\text { Laba Bersih Tahun } t}{\text { Laba Bersih Tahun } t-1} \times 100 \%
$$

\section{Variable Dependen (Y) \\ Transfer Pricing}

Menurut Noviastika, dkk. (2016) dalam Saraswati dan Sujana (2017) variabel transfer pricing diukur salah satunya dengan mendeteksi terjadinya penjualan kepada pihak istimewa. Penjualan kepada pihak istimewa diindikasikan terdapat transfer pricing. Penentuan harga terhadap penjualan kepada pihak berelasi biasanya mengesampingkan prinsip kewajaran bisa dengan menaikkan atau menurunkan harga.

Menurut Refgia (2017) transfer pricing merupakan suatu kebijakan perusahaan dalam menentukan keputusan untuk menentukan harga transfer antara pihak-pihak yang memiliki hubungan istimewa. Harga transfer tersebut digunakan untuk transaksi seperti barang, jasa, harta tidak berwujud, ataupun transaksi financial dengan tujuan memaksimalkan laba.

Penelitian ini menggunakan nilai transaksi pihak berelasi karena transfer pricing dan transaksi pihak berelasi merupakan transaksi yang memiliki hubungan istimewa. variabel transfer pricing diproksikan dengan ada atau tidaknya penjualan kepada pihak istimewa. Penjualan kepada pihak istimewa diindikasikan terdapat praktik transfer pricing. Harga yang ditetapkan dalam penjualan terhadap pihak berelasi biasanya mengesampingkan prinsip kewajaran bisa dengan menaikkan atau menurunkan harga (Noviastika dkk. 2016).

Kriteria dummy yang digunakan adalah nilai 1 apabila perusahaan melakukan transaksi penjualan kepada pihak istimewa, sedangkan nilai 0 untuk 
entitas yang tidak mengadakan transaksi penjualan kepada pihak istimewa. (Hartati et al., 2015).

\section{Operasional Variabel dan Skala Pengukuran}

Operasional variabel diperlukan untuk menjabarkan variabel penelitian dalam konsep indikator yang bertujuan memudahkan pengertian dan menghindari perbedaan persepsi pada penelitian ini. Operasional variabel dalam penelitian ini adalah kualitas audit, komisaris independen dan ukuran perusahaan sebagai variabel independent serta penghindaran pajak sebagai variabel dependen yang dapat dilihat dalam tabel berikut

\section{Tabel 1}

Variable Operasional Penelitian

\begin{tabular}{|c|c|c|}
\hline Variabel & Skala pengukuran & Skala Data \\
\hline $\begin{array}{l}\text { Transfer Pricing (Y) } \\
\text { (Hartati et al., 2015) }\end{array}$ & $\begin{array}{c}\text { Perusahaan yang melakukan penjualan } \\
\text { kepada pihak yang mempunyai hubungan } \\
\text { istimewa diberi nilai } 1 \text { dan yang tidak } \\
\text { diberi nilai } 0 \text { (Dummy) }\end{array}$ & Nominal \\
\hline $\begin{array}{c}\text { Beban Pajak (X1) } \\
\text { (Yuniasih et al., 2012) }\end{array}$ & $\begin{array}{c}\text { Beban Pajak diperoleh dengan cara } \\
\text { menghitung tarif pajak efektif entitas: } \\
\text { ETR }=\frac{\text { Tax Expense - Differed Tax Expense }}{\text { Earning Before Tax }} \times 100 \%\end{array}$ & Rasio \\
\hline $\begin{array}{l}\text { Tunneling Incentive (X2) } \\
\text { (Andraeni, 2017) }\end{array}$ & $\begin{array}{c}\text { Variabel tunneling incentive dapat } \\
\text { diproksikan dengan perhitungan : } \\
\text { TNC }=\frac{\text { Kepemilikan Saham Terbanyak }}{\text { Jumlah Saham Yang Beredar }} \times \mathbf{1 0 0 \%}\end{array}$ & Rasio \\
\hline
\end{tabular}

\section{Populasi dan Sampel}

Populasi dalam penelitian ini adalah seluruh perusahaan manufaktur yang terdfatar pada Bursa Efek Indonesia (BEI) periode tahun 2016-2019 Teknik penentuan sampel yang akan digunakan dalam penelitian ini adalah teknik purposive sampling. Berikut adalah kriteria perusahaan yang dijadikan sampel dalam penelitian ini:

1. Perusahaan manufaktur yang berturut turut terdaftar di Bursa Efek Indonesia periode 2016-2019.

2. Perusahaan Manufaktur yang dikendalikan oleh perusahaan lain ataupun perusahaan afiliasi dengan persentase kepemilikan 20\% atau lebih (PSAK No.15).

3. Perusahaan Manufaktur yang konsisten mengalami laba selama periode penelitian.

4. Perusahaan Manufaktur yang menggunakan mata uang Rupiah

5. Perusahaan manufaktur yang menyediakan informasi lengkap terkait variable penelitian periode 2016 - 2019 


\section{HASIL DAN PEMBAHASAN \\ Deskripsi Objek Penelitian}

Objek dalam penelitian ini adalah seluruh perusahaan manufaktur yang terdaftar di BEI periode 2016-2019 dengan total populasi sebanyak 192 perusahaan manufaktur. Berdasarkan teknik purposive sampling yang dapat dilihat pada tabel 2, maka diperoleh sampel sebanyak 65 perusahaan manufaktur dan dengan periode penelitian selama 4 tahun maka total sampel penelitian ini berjumlah 260 .

Tabel 2

Proses Pemilihan Sampel

\begin{tabular}{|c|c|c|c|}
\hline No & Kriteria & $\begin{array}{c}\text { Tidak } \\
\text { sesuai } \\
\text { kriteria }\end{array}$ & akumulasi \\
\hline 1 & $\begin{array}{l}\text { Perusahaan Manufaktur yangterdaftar di BEI periode } \\
\text { 2016-2019 (Populasi) }\end{array}$ & & 192 \\
\hline 2 & $\begin{array}{l}\text { Perusahaan Manufaktur yang tidak menerbitkan laporan } \\
\text { keuangannya per } 31 \text { Desember periode 2016-2019 }\end{array}$ & (6) & 186 \\
\hline 3 & $\begin{array}{l}\text { Perusahaan Manfaktur yang tidak terdaftar secara } \\
\text { berturut-turut periode 2016-2019 }\end{array}$ & $(40)$ & 146 \\
\hline 4 & $\begin{array}{l}\text { Perusahaan Manufaktur yang menggunakan mata uang } \\
\text { selain } \\
\text { rupiah di laporan keuangannya periode } 2016-2019\end{array}$ & $(22)$ & 124 \\
\hline 5 & $\begin{array}{l}\text { Perusahaan Manufaktur yang mengalami rugi periode } \\
\text { 2016-2019 }\end{array}$ & (9) & 115 \\
\hline 6 & $\begin{array}{l}\text { Perusahaan Manufaktur yang tidak menyediakan } \\
\text { informasi lengkap terkait variabel penelitian periode } \\
\text { 2016-2019 }\end{array}$ & $(28)$ & 87 \\
\hline 7 & $\begin{array}{l}\text { Perusahaan Manufaktur yang tidak memiliki kepemilikan } \\
\text { saham entitas lain lebih dari 20\% periode } 2016-2019\end{array}$ & $(22)$ & 65 \\
\hline \multicolumn{2}{|r|}{ Jumlah Perusahaan Manufaktur yang terpilih menjadi sampel } & & 65 \\
\hline \multicolumn{2}{|c|}{ Periode Penelitian 2016 - 2019 ( 4 tahun ) } & & 4 \\
\hline \multicolumn{2}{|c|}{ Total sampel penelitian } & & 260 \\
\hline
\end{tabular}

Sumber: Data Diolah Sendiri, 2020

\section{Statistik Deskriptif}

Tabel 3

Descriptive Statistics

\begin{tabular}{|l|r|r|r|r|r|}
\hline & $\mathrm{N}$ & Minimum & Maximum & Mean & Std. Deviation \\
\hline ETR (X1) & 260 &, 01 &, 97 &, 2826 &, 14173 \\
TNC (X2) & 260 &, 21 &, 93 &, 5591 &, 21542 \\
ITTRENDLB (X3) & 260 &, 0500 & 915,1000 & 6,540615 & 65,4755993 \\
TP (Y) & 260 &, 0 & 1,0 &, 964 &, 1865 \\
Valid N (listwise) & 260 & & & & \\
\hline
\end{tabular}


Berdasarkan hasil output SPSS 23 yang dapat dililhat pada tabel 3 di atas menunjukkan jumlah sampel (N) sebanyak 260. Nilai rata rata yang diperoleh dari variable beban pajak adalah sebesar 28,26\% lebih besar dari nilai standar deviasinya 14,17\%. Hal ini menunjukkan bahwa ada 28,26\% dari total 260 sampel mampu menghasilkan laba bersih setelah bunga dan pajak sebesar 28,26\% dari penjualan bersihnya. Nilai rata-rata (mean) variabel Tunneling Incentive sebesar 55,9\% dengan standar deviasi sebesar 21,5\%. Hal ini menunjukkan bahwa dari 260 sampel tersebut rata-rata perusahaan mempunyai kepemilikan saham mayoritas dengan kepemilikan saham diatas $20 \%$ sebagai pengendalinya. Nilai rata-rata (mean) variabel mekanisme bonus sebesar $654,06 \%$ dengan standar deviasi $6547,55 \%$. Hal ini menunjukan bahwa sebagian besar sampel penelitian mengalami peningkatan laba sekitar 6 kali lipat setiap tahunnya. Untuk variabel Transfer pricing yang menunjukkan nilai minimum sebesar 0 dan nilai maksimumnya sebesar 1. Sementara untuk nilai mean sebesar 0,96 dengan standar deviasi sebesar 0,187. Hal ini menunjukkan bahwa ada $96 \%$ dari total 260 sampel perusahaan yang melakukan praktik transfer pricing dan sisanya sejumlah $4 \%$ tidak melakukan Transfer pricing.

\section{Menilai Keseluruhan Model Fit}

\section{Tabel 4}

Pengujian -2log likelihood Block 0

\begin{tabular}{|lc|c|c|}
\hline \multicolumn{5}{|c|}{ Iteration History $^{\mathbf{a}, \mathbf{b}, \mathbf{c}}$} \\
\cline { 4 - 4 } & Iteration & -2 Log likelihood & Coefficients \\
\hline $\mathrm{S}$ & 1 & 82,605 & Constant \\
$\mathrm{t}$ & 2 & 63,110 & 1,856 \\
$\mathrm{e}$ & 3 & 60,443 & 2,705 \\
$\mathrm{p}$ & 4 & 60,325 & 3,161 \\
& 5 & 60,325 & 3,283 \\
0 & 6 & 60,325 & 3,291 \\
& & & 3,291 \\
\hline
\end{tabular}

a. Constant is included in the model.

b. Initial -2 Log Likelihood: 60,325

c. Estimation terminated at iteration number 6 because parameter estimates changed by less than, 001 .

Sumber: Hasil Output SPSS 23, 2020

Table 5

Pengujian -2log likelihood Block 1 Iteration History $\mathbf{a , b , c , d}$

\begin{tabular}{|l|c|c|c|c|c|}
\hline & & \multicolumn{4}{|c|}{ Coefficients } \\
\cline { 3 - 6 } & \multirow{2}{*}{ Iteration } & \multicolumn{4}{|c|}{} \\
\cline { 3 - 6 } & -2 Log likelihood & Constant & ETRX1 & TNCX2 & ITTRENDLBX3 \\
\hline
\end{tabular}




\begin{tabular}{|ll|r|r|r|r|r|}
\hline Step 1 & 1 & 72,875 & 2,065 & $-2,265$ &, 768 &, 000 \\
& 2 & 44,182 & 2,796 & $-3,969$ & 2,090 &, 001 \\
& 33,861 & 2,636 & $-5,071$ & 4,551 &, 002 \\
& 28,703 & 1,818 & $-5,945$ & 8,312 &, 003 \\
& 25,937 &, 775 & $-7,048$ & 13,137 &, 007 \\
& 24,419 &,- 316 & $-8,425$ & 18,318 &, 050 \\
6 & 23,573 & $-1,151$ & $-9,619$ & 22,037 &, 166 \\
7 & 23,193 & $-1,534$ & $-10,160$ & 23,390 &, 327 \\
8 & 23,072 & $-1,714$ & $-10,258$ & 23,620 &, 478 \\
9 & 23,059 & $-1,783$ & $-10,300$ & 23,705 &, 546 \\
10 & 23,059 & $-1,792$ & $-10,308$ & 23,721 &, 554 \\
11 & 23,059 & $-1,792$ & $-10,308$ & 23,721 &, 554 \\
\hline
\end{tabular}

a. Method: Enter

b. Constant is included in the model.

c. Initial -2 Log Likelihood: 60,325

d. Estimation terminated at iteration number 12 because parameter estimates changed by less than ,001.

Sumber: Hasil Output SPSS 23, 2020

Pada tabel 5 di atas dimana 3 variabel independen sudah dimasukkan ke dalam model menunjukkan nilai -2 log likehood akhir (Blok 1: Method Enter) sebesar 23,059. Hal ini menunjukkan bahwa terdapat penurunan nilai $-2 \log$ likelihood yaitu sebesar 37,266. Penurunan nilai -2 log likelihood ini menunjukkan bahwa dengan memasukkan variabel independen ke dalam model dapat memperbaiki model fit serta menunjukkan model regresi yang lebih baik, yang berarti H0 diterima dengan kata lain model fit dengan data dan dapat melanjutkan proses pengujian selanjutnya.

\section{Menilai Kelayakan Model Regresi}

Dalam penelitian ini untuk menilai kelayakan model regresi dengan menggunakan Hosmer and Lemeshow's Goodness of Fit Test (Ghozali, 2016:329). Hipotesis yang digunakan untuk menilai keayakan model regresi adalah sebagai berikut:

1. Jika nilai Statistics Hosmer and Lemeshow's Goodness of Fit Test $<0,05$ maka $\mathrm{H} 0$ ditolak, yang berarti bahwa model tidak dapat memprediksi nilai observasinya.

2. Jika nilai Statistics Hosmer and Lemeshow's Goodness of Fit Test >0,05 maka H0 diterima, yang berarti bahwa model dapat memprediksi nilai observasinya. Hasil pengujian kelayakan model regresi dapat dilihat pada tabel berikut: 
Table 6

Pengujian Hosmer and Lemeshow

Hosmer and Lemeshow Test

\begin{tabular}{|c|c|c|c|}
\hline Step & Chi-square & Df & Sig. \\
\hline 1 & 4,775 & 8 & 781 \\
\hline
\end{tabular}

Sumber: Hasil Output SPSS 23, 2020

Hasil yang dapat dilihat pada tabel 6 di atas menunjukkan nilai chisquare sebesar 4,775 dengan nilai signifikansi 0,781 >0,05, dengan nilai signifikansi yang lebih besar dari 0,05 maka H0 diterima. Hal ini berarti bahwa tidak ada perbedaan antara model dengan data. Dengan demikian dapat disimpulkan bahwa model dapat memprediksi nilai observasinya atau dapat dikatakan model dapat diterima karena cocok dengan data observasinya.

\section{Uji Koefisien Determinasi}

Pengujian koefisien determinasi digunakan untuk mengetahui seberapa jauh kemampuan model variabel independen yaitu beban Pajak, Tunneling Incentive. dan mekanisme bonus dalam menerangkan variasi variabel dependen yaitu transfer pricing. Dalam model regresi logistik besarnya nilai koefisien determinasi ditunjukkan dengan nilai Nagelkerke R Square yang dapat diinterpretasikan seperti nilai R2 pada regresi berganda.

Tabel 7

Pengujian Koefisien Determinasi Model Summary

\begin{tabular}{|l|c|c|c|}
\hline Step & $\begin{array}{c}-2 \mathrm{Log} \\
\text { likelihood }\end{array}$ & $\begin{array}{c}\text { Cox \& Snell R } \\
\text { Square }\end{array}$ & $\begin{array}{c}\text { Nagelkerke R } \\
\text { Square }\end{array}$ \\
\hline 1 & $23,059^{\mathrm{a}}$ &, 174 &, 654 \\
\hline
\end{tabular}

Pada tabel 7 di atas menunjukkan nilai Nagelkerke R Square yaitu sebesar 0,654 yang menunjukkan bahwa kemampuan variabel independen yaitu Beban pajak, Tunneling Incentive dan Mekanisme Bonus dalam menjelaskan variabel dependen yaitu Transfer Pricing sebesar 65,4\%, sedangkan sisanya sebanyak 34,6\% variabel lain diluar model penelitian yang dapat menjelaskan variabel Transfer Pricing.

\section{Uji Omnibus}

Pengujian ini dilakukan dengan tujuan untuk mengetahui pengaruh secara simultan variabel independen terhadap variabel dependen atau minimal ada satu variabel independen yang berpengaruh terhadap variabel dependen. Omnibus test ini mirip dengan uji $\mathrm{F}$ pada nalisis regresi linier berganda. Nilai pada uji ini dapat dilihat dengan menggunakan nilai pvalue yang dibandingkan dengan nilai $\alpha$, dengan kriteria pengambilan keputusan sebagai berikut: 
1. Jika $p$-value $>\alpha(0,05)$, maka variabel-variabel independen secara simultan tidak berpengaruh terhadap penghindaran pajak atau $\mathrm{H} 0$ diterima.

2. Jika p-value $<\alpha(0,05)$, maka variabel-variabel independen secara simultan berpengaruh atau minimal ada satu variabel independen yang berpengaruh terhadap Transfer Pricing atau H0 ditolak.

\section{Tabel 8}

Omnibus Tests of Model Coefficients
\begin{tabular}{|cl|r|r|r|}
\hline & Chi-square & df & \multicolumn{1}{c|}{ Sig. } \\
\hline Step 1 & Step & 37,266 & 3 &, 000 \\
& Block & 37,266 & 3 &, 000 \\
& Model & 37,266 & 3 &, 000 \\
\hline
\end{tabular}

Dapat dilihat pada Tabel 8 di atas hasil omnibus test menunjukkan bahwa nilai pvalue sebesar $0,00<0,05$. Nilai p-value yang menunjukkan lebih kecil dari tingkat signifikansi sebesar 0,05, maka $\mathrm{H} 0$ ditolak yang berarti bahwa beban pajak, tunneling incentive dan mekanisme bonus secara simultan berpengaruh terhadap praktik transfer pricing.

\section{Pengujian Hipotesis}

Pengujian hipotesis dalam penelitian ini bertujuan untuk mengetahui pengaruh beban pajak, Tunneling incentive dan mekanisme bonus sebagai variabel independen terhadap penghindaran pajak sebagai variabel dependen. Pengujian hipotesis ini dilakukan dengan menggunakan hasil uji regresi logistik yang ditunjukkan dengan tabel hasil ouput spss variables in equation dengan nilai pada kolom significant yang dibandingkan dengan tingkat kealphaan 5\%. Hasil pengujian ini dapat dilihat pada tabel berikut:

Tabel 9

\section{Pengujian Hipotesis}

Variables in the Equation

\begin{tabular}{|c|c|c|c|c|c|c|c|c|c|}
\hline & \multirow[b]{2}{*}{$B$} & \multirow[b]{2}{*}{ S.E. } & \multirow[b]{2}{*}{ Wald } & \multirow[b]{2}{*}{ df } & \multirow[b]{2}{*}{ Sig. } & \multirow[b]{2}{*}{$\operatorname{Exp}(B)$} & \multicolumn{2}{|c|}{$95 \%$ C.Ifor EXP(B) } \\
\hline & & & & & & & & Lower & Upper \\
\hline \multirow[t]{4}{*}{ Step $1^{\text {a }}$} & ETR &,- 103 &, 043 & 5,754 & 1 &, 016 &, 902 &, 829 & ,981 \\
\hline & TNC &, 237 & 102 & 5,390 & 1 &, 020 & 1,268 & 1,038 & 1,549 \\
\hline & ITTRENDLB &, 006 &, 007 &, 626 & 1 & .429 & 1,006 &, 992 & 1,019 \\
\hline & Constant & $-1,792$ & 2,240 &, 639 & 1 &, 424 & 167 & & \\
\hline
\end{tabular}

a. Variable(s) entered on step 1: ETR, TNC, ITTRENDLB.

Sumber: Hasil Output SPSS 23, 2020

Dapat dilihat pada tabel 9, menunjukkan hasil uji regresi logistik pada tingkat signifikansi $(\alpha) 5 \%$. Dari hasil pengujian regresi logistik tersebut, maka persamaan regresinya adalah sebagai berikut:

$$
\operatorname{Ln}(\mathrm{Y} / 1-\mathrm{Y})=-1,792-0,103 E T R+0,237 \mathrm{TNC}+0,006 \text { ITTRENDLB }+\varepsilon
$$

Keterangan: 


$\begin{array}{lll}\operatorname{Ln}(\mathrm{Y} / 1-\mathrm{Y}) & =\text { Logaritma probabilitas perusahaan melakukan } \\ & \text { transfer pricing } \\ \beta 0 & =\text { Konstanta } \\ \text { ETR } & =\text { Beban Pajak } \\ \text { TNC } & =\text { Tunneling Incentive } \\ \text { ITTRENDLB } & =\text { Mekanisme Bonus } \\ \varepsilon & =\text { Error term }\end{array}$

Berdasarkan persamaan regresi di atas dan tabel 9, maka akan dijelaskan analisis sebagai berikut:

1. Nilai konstanta pada persamaan regresi di atas sebesar -1,792 artinya jika beban pajak, Tunneling Incentive dan mekanisme bonus tidak diperhitungkan, maka praktik transfer pricing adalah sebesar $-1,792$.

2. Hasil pengujian hipotesis pertama menunjukkan bahwa variabel dari Beban pajak mempunyai koefisien regresi negatif sebesar -0,103 dengan tingkat signifikansi sebesar 0,016 yang lebih kecil dari $\alpha(5 \%)$. Koefisien regresi negatif menunjukkan setiap kenaikan Beban Pajak (ETR) sebesar 1 (satu) poin maka kecenderungan terjadi penurunan tindakan Transfer Pricing sebesar 0,103. Koefisien variabel beban pajak yang bernilai negatif menunjukkan bahwa hubungan beban pajak dengan praktik transfer pricing berlawanan, jika beban pajak meningkat maka transfer pricing menurun dan begitu juga sebaliknya.

3. Hasil pengujian hipotesis kedua menunjukan bahwa variabel Tunneling Icnentive yg dihitung dengan membandingkan jumlah kepemillikan saham terbesar dengan jumlah seluruh saham yang beredar mempunyai nilai koefisien regeresi positif sebesar 0,237 dengan tingkat signifikansi sebesar 0,02 yang lebih kecil dari $\alpha(5 \%)$. Koefisien regresi positif menunjukkan setiap kenaikan Tunneling Incentive (TNC) sebesar 1 (satu) poin maka kecenderungan terjadi peningkatan praktik transfer pricing sebesar 0,237. Koefisien variabel Tunneling incentive yang bernilai positif menunjukkan bahwa hubungan Tunneling Incentive dengan praktik transfer pricing searah, jika tunnelling incentive naik maka praktik transfer pricing juga naik dan begitu sebaliknya.

4. Hasil pengujian hipotesis ketiga menunjukkan bahwa variabel mekanisme bonus yang dihitung dengan membandingkan laba perusahaan pada tahun berjalan dengan laba perusahaan pada tahun sebelumnya memiliki nilai koefisien regresi positif sebesar 0,006 dengan tingkat signifikansi sebesar 0,429 yang lebih besar dari $\alpha(5 \%)$. Koefisisen regresi positif menunjukkan setiap kenaikan mekanisme bonus (ITTRENDLB) sebesar 1 (satu) poin maka kecenderungan terjadi praktik transfer pricing sebesar 0,006. Koefisien variabel mekanisme bonus yang bernilai positif menunjukkan bahwa hubungan mekanisme bonus dengan transfer pricing searah, yang berarti jika mekanisme bonus meningkat maka praktik transfer pricing juga meningkat dan begitu juga sebaliknya.

\section{Interpretasi Hasil penelitian}

\section{Pengaruh beban pajak terhadap praktik transfer pricing}

Jurnal Ilmiah Akuntansi dan Ekonomi Volume. 5 Nomor. 2, Agustus 2020 Hal. 33 
Pada tabel 9, kita ketahui dimana beban pajak yang ditentukan dengan nilai efektifitas rasio pajak nya (ETR) menunjukkan nilai koefisien sebesar -0,103 dengan tingkat signfikansi sebesar 0,016. Dimana hal ini menunjukkan bahwa tingkat signifikansi beban pajak lebih kecil dari $\alpha(5 \%)$, yaitu $0,016<0,05$. Kesimpulan dari hasil uji tersebut bahwa Ha1 diterima, yang berarti bahwa variabel beban pajak berpengaruh terhadap transfer pricing. Hal ini menunjukan bahwa alasan perusahaan melakukan transfer pricing adalah karena besarnya beban pajak, terutama pajak penghasilannya. Tujuan utama perusahaan melakukan transfer pricing salah satunya adalah untuk menekan beban pajak yang semakin besar karena dalam praktik bisnis, pengusaha mengidentifikasi pembayaran pajak sebagai beban sehingga cenderung diminimalkan dengan cara transfer pricing, bila beban pajak ditekan makan cost berkurang dan laba meningkat. Hasil penelitian ini sesuai atau sejalan dengan penelitian yang dilakukan oleh Wafiroh dan Hapsari (2016). Namun tidak sejalan dengan penelitian yang dilakukan oleh Mispiyanti (2015).

\section{Pengaruh Tunneling Incentive terhadap praktik transfer pricing}

Berdasarkan hasil pengujian hipotesis pada tabel 9, menunjukan koefisien dari tunneling incentive sebesar 0,0237 dengan tingkat signifikansi sebesar 0,02. Dimana hal ini menunjukkan bahwa tingkat signifikansi lebih kecil dari $\alpha(5 \%)$, yaitu $0,02<0,05$. Kesimpulan dari hasil pengujian menunjukkan Ha2 diterima, yang berarti bahwa tunnelling incentive berpengaruh terhadap praktik transfer pricing. Hal ini menunjukkan bahwa semakin banyak kepemilikan saham mayoritas maka semakin cenderung perusahaan melakukan transfer pricing dengan tujuan utama adalah menghasilkan lebih banyak laba untuk pengendalinya. Jika pemilik saham mayoritas mempunyai kepemilikan yangbesar, dengan kata lain mereka telah menanamkan modal yang juga besar kedalam perusahaan tersebut. Maka otomatis mereka juga menginginkan pengembalian atau dividen yang besar pula. Untuk itu ketika dividen yang dibagikan perusahaan tersebut harus dibagi dengan pemilik saham minoritas, maka pemiliksaham mayoritas lebih memilih untukmelakukan transfer pricing dengan cara mentransfer kekayaan perusahaan untuk kepentinganya sendiri dari pada membagi dividennya kepada pemilik saham minoritas. Oleh sebab itu, semakin besar kepemilikan pemegang saham maka akan semakin memicu terjadinya praktik transfer pricing. Hasil penelitian ini sejalan atau mendukung penelitian yang dilakukan oleh Mispiyanti (2015) yang menyatakan tunnelling incentive berpengaruh terhadap keputusan transfer pricing.

\section{Pengaruh Mekanisme Bonus terhadap praktik transfer pricing}

Berdasarkan hasil pengujian hipotesis yang telah dilakukan sebelumnya yang dapat dilihat pada tabel 9, menunjukkan bahwa koefisien dari ukuran perusahaan sebesar 0,006 dengan tingkat signifikansi sebesar 0,429. Tingkat signifikansi 0,429 > 0,05 memberi kesimpulan Ha3 ditolak, yang berarti bahwa mekanisme bonus tidak berpengaruh terhadap praktik transfer pricing. Artinya, jika hanya karena motif untuk mendapatkan bonus, tidak seharusnya direksi berani melakukan transaksi transfer pricing untuk meningkatkan laba perusahaan tetapi direksi dapat melakukan manajemen perusahaan yang baik yang dapat berpengaruh terhadap

Jurnal Ilmiah Akuntansi dan Ekonomi Volume. 5 Nomor. 2, Agustus 2020 Hal. 34 
pencapaian laba yang maksimal, mengingat hal ini sangat tidak etis karna manajemen perusahaan harus menjaga nilai perusahaan dimata masyarakat. Hasil penelitian ini selaras atau mendukung penelitian yang telah dilakukan oleh Saraswati dan Sujana (2017) serta Mispiyanti (2017) yang menyatakan bahwa mekanisme bonus tidak berpengaruh terhadap penerapan transfer piricing perusahaan. Sementara hasil penelitian ini tidak selaras dengan penelitian yang dilakukan oleh Refgia (2017), Wafiroh dan Hapsari (2016) yang menyatakan sebaliknya, mekanisme berpengaruh dalam penerapan transfer pricing perusahaan.

\section{Kesimpulan}

\section{KESIMPULAN DAN SARAN}

Berdasarkan hasil analisis yang telah dijelaskan pada bab sebelumnya dimana penelitian ini bertujuan untuk mengetahui pengaruh variabel independen yang terdiri dari beban pajak, tunneling incentive, dan mekanisme bonuse terhadap variabel dependen yaitu penerapan transfer pricing pada perusahaan manufaktur yang terdaftar di Bursa Efek Indonesia periode 2016-2018, maka kesimpulan dari penelitian ini adalah sebagai berikut:

1. Beban pajak berpengaruh negatif terhadap penerapan transfer pricing. Hal ini dapat dilihat dengan besaran tingkat signifikansi pada table 4.8 variable in the Equation sebesar 0,016

2. Tunneling Incentive juga berpengaruh terhadap penerapan transfer pricing, yang mempunyai nilai signifikansi sebesar 0,02 yang dapat kita lihat pada table 4.8 variable in the Equation

3. Namun, berbeda dengan variable mekanisme bonus yang tidak berpengaruh terhadap penerapan transfer pricing dengan nilai signifikansi sebesar 0,429 yang dapat dilihat dalam table 4.8 variable in the Equation

\section{Saran}

Berdasarkan kesimpulan dan keterbatasan dalam penelitian ini, maka saran untuk penelitian selanjutnya dengan variabel dependen yang sama adalah sebagai berikut:

1. Penelitian selanjutnya diharapkan dapat menambah atau menggunakan variabel independen lain yang diteliti sehingga dapat lebih akurat dalam memprediksi pengaruhnya terhadap penerapan transfer picing. Berdasarkan teori serta penelitian sebelumnya, penelitian selanjutnya dapat menambah variabel independen lain seperti: kepemilikan asing, besarnya perusahaan dan exchange rate.

2. Penelitian selanjutnya diharapkan dapat memperluas populasi yang digunakan dengan menambahkan sektor lain yang terdaftar di Bursa Efek Indonesia dengan maksud untuk mengetahui apakah faktor faktor yang mempengaruhi transfer pricing dapat dilihat pada sektor lainnya. Selain itu pula penelitian selanjutnya dapat menambahkan periode penelitian sehingga penelitian dapat dijelaskan lebih luas lagi.

3. Peneliti selanjutnya diharapkan dapat mencari literatur-literatur yang terkait dengan variabel penelitian dengan lebih baik lagi sebelum memulai penelitian. 


\section{DAFTAR PUSTAKA}

Ghozali, Imam. 2016. Aplikasi Analisis Multivariate dengan Program IBM SPSS 21 Update PLS Regresi. Semarang: Badan Penerbit Universitas Diponegoro.

Gunadi, 2007. “Pajak Internasional”, Ed. Revisi, Jakarta, LPFEUI.

Harahap, Sofyan Syafri. 2012. Teori Akuntansi, Jakarta: Rajawali Pers.

M. Zain, 2008. Manajemen Perpajakan. Jakarta: Salemba Empat.

Resmi, Siti. 2017. Perpajakan. Jakarta: Salemba Empat

Scott, William R. 2015. Financial Accounting Theory Fifth Edition. Toronto: Prentice Hall

Siti Kurnia Rahayu, 2010. PERPAJAKAN INDONESIA : Konsep dan Aspek Formal, Yogyakarta : Graha Ilmu.

Sugiyono. 2016. Metode Penelitian Kuantitatif, Kualitatif, dan R\&D. Bandung: Alafabeta

Sulistyanto, H. Sri. 2008. Manajemen Laba, Teori dan Model Empiris. Jakarta: Grasindo

Watts, Ross L. dan Jerold L. Zimmerman (1986). Positive Accounting Theory. USA: Prentice-Hall. 